\title{
Establishment of a recombinant expression system for connective tissue growth factor (CTGF) that models CTGF processing in utero
}

\author{
D. K. Ball ${ }^{1,2}$, E. E-D. A. Moussad ${ }^{1,2}$, M. A. E. Rageh ${ }^{1,2}$, S. A. Kemper² \\ and D. R. Brigstock ${ }^{1,2,3 *}$ \\ ${ }^{1}$ Department of Surgery and ${ }^{3}$ Department of Molecular and Cellular Biochemistry, The Ohio State \\ University, Columbus, OH 43210, USA; and ${ }^{2}$ Center for Cellular and Vascular Biology, \\ Children's Research Institute, Columbus, $\mathrm{OH} 43205$, USA
}

Connective tissue growth factor (CTGF) stimulates cell proliferation, migration, adhesion and extracellular matrix production, and functions in processes such as development, differentiation, angiogenesis, implantation, wound healing and fibrosis. CTGF is a $38 \mathrm{kDa}$ protein that comprises four discrete structural modules (modules 1-4) but is susceptible to limited proteolysis in utero yielding bioactive isoforms that comprise either modules 3 and $4(16-20 \mathrm{kDa})$ or module $4(10 \mathrm{kDa})$. Here we report the development of a stable cell line, termed DB1, that was generated by transfecting cDNA encoding full-length human CTGF into Chinese hamster ovary cells that were mutant for heparin sulphate and chondroitin sulphate. DB1 cells produced $38 \mathrm{kDa}$ CTGF and low molecular mass CTGFs that had $\mathrm{N}$-termini between modules 2 and 3 at $\mathrm{Ala}^{181}$ (20 kDa), Leu ${ }^{184}$ (18 kDa) or Ala ${ }^{197}$ (16 kDa) or between modules 3 and 4 at Gly ${ }^{253}$ (10 kDa). CTGF was exported from DB1 cells as early as $5 \mathrm{~min}$ after synthesis and all isoforms were readily purified from conditioned medium by sequential steps of heparin affinity, cation exchange, and reverse-phase chromatography. The $38 \mathrm{kDa}$ CTGF was faithfully glycosylated and underwent limited proteolysis in the presence of thrombin, kallikrein or uterine fluids, the last of which was antagonized by anti-thrombin III. All CTGF isoforms promoted cell adhesion, mitosis and epithelial transdifferentiation in vitro as well as subcutaneous fibrosis in vivo. The establishment of this recombinant expression system allows for massscale production of all previously reported uterine CTGF isoforms, demonstrates that module 4 contains functional domains involved in a broad range of biological activities, and will facilitate studies of CTGF processing in vitro.

\section{Introduction}

Connective tissue growth factor (CTGF) is a multifunctional polypeptide that regulates several aspects of cell function including differentiation, proliferation, survival, migration, adhesion and stimulation of extracellular matrix production (Grotendorst, 1997; Brigstock, 1999; Lau and Lam, 1999; Moussad and Brigstock, 2000; Perbal, 2001). CTGF is a $38 \mathrm{kDa}$ protein comprising four discrete structural modules that are found in a variety of unrelated extracellular proteins (Bork, 1993; Brigstock, 1999). These modules contain motifs that predict potential roles in insulin-like growth factor (IGF) binding (module 1), oligomerization (module 2), cell attachment (module 3), and dimerization or receptor binding (module 4). It is likely that the modular

\footnotetext{
*Address for correspondence: Children's Research Institute, Room W309, 700 Children's Drive, Columbus, OH 43205, USA

Email: brigstod@pediatrics.ohio-state.edu
}

configuration of CTGF allows it to interact with soluble, cellular or extracellular proteins associated with the matrix. These interactions may regulate the activity and bioavailability of CTGF and its binding partners within the pericellular environment (Brigstock, 1999; Moussad and Brigstock, 2000; Perbal, 2001).

Many different cell types produce and respond to CTGF and it is likely that autocrine and paracrine circuits are responsible for its actions (Moussad and Brigstock, 2000). Although CTGF overproduction and action has been linked to various fibrotic and desmoplastic pathologies (Grotendorst, 1997; Brigstock, 1999; Clarkson et al., 1999; Goldschmeding et al., 2000; Gupta et al., 2000; Moussad and Brigstock, 2000; Denton and Abraham, 2001), several studies have highlighted the likely importance of this molecule in normal biological processes such as wound repair (Igarashi et al., 1993; Pawar et al., 1995; Schwab et al., 2000; Ujike et al., 2000; Wunderlich et al., 2000; Blom et al., 2001), endochondral ossification (Nakanishi et al., 1997, 2000, 2001; Nishida et al., 2000) and angiogenesis (Shimo 
et al., 1999). Within the context of the reproductive tract, both the uterus and ovary of the adult have been identified as sites of CTGF production and action. Ovarian CTGF expression is regulated by transforming growth factor $\beta$ (TGF- $\beta$ ) and gonadotrophins (Harlow et al., 2002; Liu et al., 2002), whereas uterine CTGF expression is regulated by TGF- $\beta$, oestrogen and progesterone (Rageh et al., 2001). Cysteine-rich 61 (CYR61), which is $80 \%$ homologous to CTGF, is also oestrogenand progesterone-dependent (Sampath et al., 2001a, 2002; Xie et al., 2001a), and both CYR61 and CTGF are expressed in steroid-dependent tumours of the breast or uterus (Frazier and Grotendorst, 1997; Tsai et al., 2000, 2002; Uzumcu et al., 2000; Sampath et al., 2001a,b, 2002; Xie et al., 2001a,b). Thus CTGF and CYR61 may mediate the action of hormones and growth factors in the reproductive tract. In the ovary, CTGF has been implicated in theca cell recruitment and mitogenesis during follicular development and maintenance of the corpus luteum after ovulation (Wandji et al., 2000; Slee et al., 2001; Harlow and Hillier, 2002; Harlow et al., 2002; Liu et al., 2002). In the uterus, luminal and glandular epithelial cells are a major source of CTGF during the oestrous cycle and preimplantation (Surveyor et al., 1998; Moussad and Brigstock, 2000; Moussad et al., 2002). In species exhibiting non-invasive placentation, there is a transient decrease in CTGF production by these cells during the attachment phase, which is temporally and spatially associated with extensive stromal remodelling and neovascularization (Moussad et al., 2002). In species with invasive placentation, CTGF is downregulated in uterine luminal epithelial cells before implantation and is then markedly upregulated in decidualizing stromal cells (Surveyor et al., 1998; Uzumcu et al., 2000). Irrespective of the mode of placentation, CTGF is also produced by endothelial cells of the uterine and extraembryonic vasculature (Surveyor et al., 1998; Moussad and Brigstock, 2000; Uzumcu et al., 2000; Moussad et al., 2002). Collectively, these results indicate that CTGF is involved in driving proliferation, differentiation, angiogenesis and extracellular matrix remodelling during placentation and decidualization. CTGF has also been detected in the uterine luminal fluid (ULF) in which its concentration changes as a function of the oestrous cycle (Brigstock et al., 1997; Ball et al., 1998; Surveyor et al., 1998). In pigs, CTGF in ULF is detectable sooner in pregnancy than during the oestrous cycle (day 12 versus day 14) and exhibits overall lower concentrations and earlier peak production in pregnant animals compared with cyclic animals (day 12-14 versus day 16-18) (Ball et al., 1998), supporting a modified role for uterine CTGF during the pre- and peri-attachment periods.

ULF was found to contain stable C-terminal isoforms of CTGF, which comprise essentially modules 3 and 4 (16-20 kDa) or module 4 alone (10-12 kDa) (Brigstock et al., 1997; Ball et al., 1998). These proteins were detected in ULF of pigs and mice and arise via limited proteolysis of the $38 \mathrm{kDa}$ uterine CTGF protein (Brigstock et al., 1997; Ball et al., 1998; Surveyor et al., 1998). Low molecular mass CTGF isoforms possess some of the biological and physicochemical properties as full-length CTGF showing that functional domains reside within the C-terminal region of CTGF. Similar, but non-identical low molecular mass CTGF isoforms have been reported in amniotic, follicular, peritoneal, cerebrospinal fluids, serum and in conditioned medium of various mammalian cell lines maintained in vitro (Steffen et al., 1998; Yang et al., 1998; Boes et al., 1999; Williams et al., 2000). Although not yet proven, it is expected that the presence of modules 3 or 4 , but not modules 1 or 2 , will affect the repertoire of binding interactions of low molecular mass isoforms compared with the intact molecule.

Although the early studies of uterine secretory CTGF provided an important lead with respect to CTGF structure and function (Brigstock et al., 1997; Ball et al., 1998), detailed studies of low molecular mass CTGFs have been hampered by the difficulty of obtaining and processing large volumes of ULF and the relatively low yields of each isoform. Moreover, no other convenient source of these proteins is available for preparative purposes. As progress in this area is important so that the intrinsic biological properties of low molecular mass CTGFs can be studied in depth, we have developed a mammalian recombinant expression system in which $38 \mathrm{kDa}$ CTGF undergoes faithful post-translational processing (glycosylation, proteolysis) and from which all CTGF isoforms can be readily purified and characterized.

\section{Materials and Methods}

\section{Establishment of a stable CTGF-producing cell line}

Full-length human CTGF cDNA was isolated by RTPCR of human foreskin fibroblast RNA as described by Steffen et al. (1998). The amplified product was verified using Sequenase Version 2 (USB, Cleveland, $\mathrm{OH}$ ) and ligated into pcDNA3.1 (Invitrogen, San Diego, CA). The ligation product, termed pcDNA3.1/CTGF, was transfected into $\mathrm{DH} 5 \alpha$ competent Escherichia coli and isolated by large-scale alkaline lysis. The protocol for lipofectamine (Gibco/BRL, Grand Island, NY) was used and $2 \mu \mathrm{g}$ pcDNA3.1/CTGF was used to transfect pgsA mutant Chinese hamster ovary $(\mathrm{CHO}) 745$ cells (deficient in xylosyltransferase; negative for heparan sulphate and chondroitin sulphate (Esko et al., 1985), kindly provided by J. Esko, University of California, San Diego, CA). After 2 days, the transfected cells were placed in Dulbecco's modified Eagle's medium (DMEM) $-10 \%$ fetal bovine serum (FBS) containing $500 \mu \mathrm{g}$ gentamycin (G418) $\mathrm{ml}^{-1}$ for selection. After 10 days, the cells were seeded in the same medium at 0.5 cells per well in six 96 -well plates. Medium from wells containing single colonies 
was screened for the presence of CTGF by western blot analysis and one clone, termed DB1, was selected for further processing.

DB1 cells were expanded into ten T-175 culture flasks in Ham's F12 (CellGro, Fisher Scientific, Pittsburgh PA) containing $10 \% \mathrm{FBS}$ and $500 \mu \mathrm{g} \mathrm{G} 418 \mathrm{ml}^{-1}(30 \mathrm{ml}$ per flask). Once the cells had reached confluency, they were trypsinized and placed in 15 Nunclon $500 \mathrm{~cm}^{2}$ triple flasks (Nalge Nunc International Corp., Naperville, IL) in fresh Ham's F12-10\% FBS-G418 medium (95 ml per flask). After 2-3 days, the medium was replaced with $85 \mathrm{ml}$ per flask of serum-free CHO-SFMII (Gibco/BRL) containing $500 \mu \mathrm{g} \mathrm{G} 418 \mathrm{ml}^{-1}$. After 3-4 days, conditioned medium was collected (approximately 1.2 I total volume), centrifuged (10000 $\mathrm{g}$ for $20 \mathrm{~min}$ ), and the supernatant clarified using a $0.2 \mu \mathrm{m}$ filter.

\section{Heparin affinity chromatography}

A first step of heparin affinity chromatography was performed either by loading conditioned medium on to an Econo-Pac heparin column $(3.6 \mathrm{~cm} \times 0.7 \mathrm{~cm}$; BioRad, Hercules, CA) at a flow rate of $1 \mathrm{ml} \mathrm{min}^{-1}$ at $4{ }^{\circ} \mathrm{C}$ (Brigstock et al., 1997) or on to a Poros HE2/P heparin column $(5.0 \mathrm{~cm} \times 0.46 \mathrm{~cm}$; Applied Biosystems, Foster City, CA) at a flow rate of $5 \mathrm{ml} \mathrm{min}{ }^{-1}$ at room temperature. A gradient of $40 \mathrm{ml}$ of $0.2-2.0 \mathrm{~mol} \mathrm{NaCl}-1$ in $10 \mathrm{mmol}$ Tris- $\mathrm{HClI}^{-1}(\mathrm{pH} 7.4)$ was used to develop each column and bound proteins were collected into fractions of $1 \mathrm{ml}$. Selected fractions from four individual first-step purifications were pooled, diluted $1: 3$ with $10 \mathrm{mmol}$ Tris-HClI-1 $(\mathrm{pH}$ 7.4), and subjected to a second step of heparin affinity chromatography using a TSK ${ }^{\circledR}$ heparin column $(7.5 \mathrm{~cm} \times 0.8 \mathrm{~cm}$; TosoHaas, Philadelphia, PA), essentially as described by Brigstock et al. (1997) and Ball et al. (1998).

\section{Cation exchange chromatography}

Selected fractions from the second step of heparin affinity chromatography were diluted $1: 3$ in $10 \mathrm{mmol}$ Tris- $\mathrm{HClI}^{-1}(\mathrm{pH} 7.4)$ and loaded on to an Econo-Pac carboxymethyl $(\mathrm{CM})$ cation exchange column $(1 \mathrm{~cm} \times$ $5 \mathrm{~cm}$; Bio-Rad, Hercules, CA). After washing the column with $10 \mathrm{ml}$ of $10 \mathrm{mmol}$ Tris- $\mathrm{HCll}^{-1}(\mathrm{pH} 7.4)-0.2 \mathrm{~mol}$ $\mathrm{NaClI}^{-1}$, the bound proteins were eluted using a gradient of $40 \mathrm{ml}$ of $0.2-2.0 \mathrm{~mol} \mathrm{NaCl}^{-1}$ at a flow rate of $1 \mathrm{ml}$ $\mathrm{min}^{-1}$ and collected into fractions of $1 \mathrm{ml}$.

\section{Reverse-phase HPLC (RP-HPLC)}

RP-HPLC was performed on pooled CM fractions as described by Brigstock et al. (1997) except that a semipreparative $\mathrm{C}_{8}$ column $(25 \mathrm{~cm} \times 1 \mathrm{~cm}, 10 \mu \mathrm{m}$; Vydac, Hesperia, CA) was used. The column was equilibrated with water containing $5 \%(\mathrm{v} / \mathrm{v})$ acetonitrile and $0.1 \%$ $(\mathrm{v} / \mathrm{v})$ trifluoroacetic acid (TFA). Selected fractions from the CM cation exchange step were pooled, adjusted to $5 \%$ acetonitrile- $0.1 \%$ TFA, and clarified using a $0.2 \mu \mathrm{m}$ filter before injection. After sample injection, the column was washed with $5 \%$ acetonitrile- $0.1 \%$ TFA for $30 \mathrm{~min}$ and then developed using a multi-linear acetonitrile gradient at a flow rate of $1 \mathrm{ml} \mathrm{min}{ }^{-1}$. Fractions were collected into tubes containing $50 \mu \mathrm{l} 0.25 \mathrm{~mol} \mathrm{NaOH} \mathrm{I} \mathrm{I}^{-1}$ to neutralize the TFA.

\section{Gel filtration chromatography}

Gel filtration HPLC was performed on a Biosep S-2000 column $(30 \mathrm{~cm} \times 0.78 \mathrm{~cm}$; separation range $827-$ 300 kDa; Phenomenex, Torrance, CA). A peak fraction $(100 \mu \mathrm{l})$ from a second step of heparin affinity chromatography was injected on to the column and eluted with $0.5 \mathrm{~mol} \mathrm{NaCl} \mathrm{I}{ }^{-1}$ in PBS at a flow rate of $0.5 \mathrm{ml} \mathrm{min}^{-1}$.

\section{DNA synthesis}

Aliquots of column fractions were tested for their ability to stimulate $\left[{ }^{3} \mathrm{H}\right]$ thymidine incorporation into DNA of Balb/c 3T3 cells as described by Brigstock et al. (1997).

\section{Cell adhesion}

PBS $(100 \mu \mathrm{l})$ containing fixed dilutions of sequential column fractions or individually quantified CTGF isoforms were incubated overnight at $4^{\circ} \mathrm{C}$ in Costar 96well round-bottom medium binding polystyrene ELISA plates (Corning Inc, Reynoldsburg, OH). Wells were blocked with $200 \mu$ I PBS containing 3\% (w/v) BSA and then incubated for $1 \mathrm{~h}$ at $37^{\circ} \mathrm{C}$ with $100 \mu \mathrm{l} \mathrm{PBS}$ containing Balbc/3T3 cells at a concentration of $5 \times 10^{5}$ cells ml $^{-1}$. Adherent cells were then fixed for 15 min with $5 \%(\mathrm{w} / \mathrm{v})$ formaldehyde and non-adherent cells were removed by washing each well three times with PBS. The remaining cells were measured by fluorescent emission from the wells at $520 \mathrm{~nm}$ following addition of $100 \mu \mathrm{l}$ Cytoquant reagent (Molecular Probes, Eugene, OR) in lysis buffer.

\section{Protein analysis}

Aliquots of column fractions were subjected to SDSPAGE, silver staining, and western blot analysis as described by Brigstock et al. (1997). N-terminal amino acid sequencing was performed on purified CTGF isoforms that had been transferred to polyvinylidene difluoride (PVDF) blots as described by Brigstock et al. (1997) and Ball et al. (1998). CTGF protein quantification was carried out using the Micro BCA Protein assay Kit (Pierce, Rockford, IL) with BSA as a standard. 

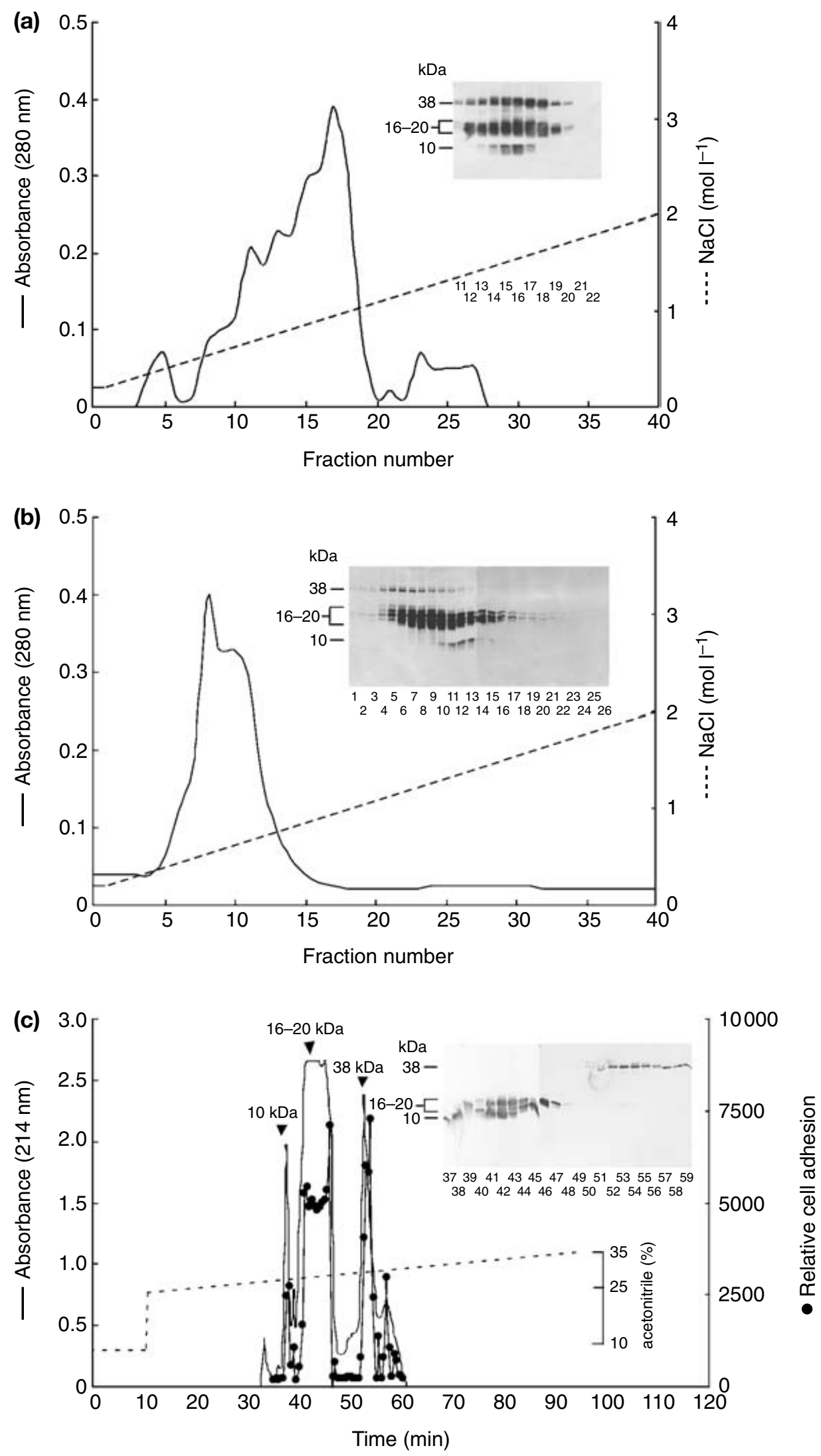

Fig. 1. For legend see facing page. 


\section{Animals}

All protocols involving animals were approved by the Institutional Animal Care and Use Committee of the Children's Research Institute, Columbus, $\mathrm{OH}$.

\section{Transdifferentiation}

Techniques published by Ross et al. (1993) were adapted to isolate corneal epithelial cells from the eyes of adult Swiss Webster mice by enzymatic digestion and differential centrifugation. Cells were cultured for 7 days in DMEM-10\% FBS and then grown for 2 days in serum-free DMEM containing insulin, transferrin and sodium selenite. This medium was then replenished and supplemented with 0-400 ng CTGF ml ${ }^{-1}$ for $24 \mathrm{~h}$, after which cells were stained for alpha smooth muscle actin $(\alpha S M A)$ using $1.7 \mu \mathrm{g}$ mouse monoclonal antibody $\mathrm{ml}^{-1}$ (clone 1A4; Dako, Denmark).

\section{Fibrosis in vivo}

A model of persistent subcutaneous fibrosis in neonatal mice was established as described by Mori et al. (1999) except that prior or co-administration of TGF- $\beta$ was omitted. Briefly, 340 ng of each CTGF isoform was administered in $20 \mu \mathrm{l}$ PBS into the subcutaneous region of the neck of Swiss Webster mice of 3 days of age consecutively for 7 days ( $n=3$ per group). Control mice $(n=3)$ received subcutaneous injections of $20 \mu \mathrm{l}$ PBS consecutively for 7 days. Mice were killed 14 days after the last injection and the treated areas were resected, fixed, sectioned and stained for $\alpha S M A$ as described above.

\section{CTGF antibody production}

Western blots were probed with a peptide antiserum raised against residues 247-260 of human CTGF as described by Brigstock et al. (1997) and Ball et al. (1998). In addition, two New Zealand White rabbits (rabbits 38A and 38B), from which blood was taken to collect preimmune serum, were injected subcutaneously with $100 \mu \mathrm{g}$ pure $38 \mathrm{kDa}$ CTGF in Freund's complete adjuvant, followed 2 weeks later by an intramuscular injection of $200 \mu \mathrm{g}$ pure $38 \mathrm{kDa}$ CTGF in Freund's incomplete adjuvant. Blood samples were collected from animals 10 days later and twice a month thereafter for collection of CTGF antiserum, which was used for radioimmunoprecipitation. The CTGF used for immunization was purified from DB1 conditioned medium by sequential two-cycle heparin affinity chromatography, cation exchange chromatography, and reversephase HPLC as described above.

\section{Radioimmunoprecipitation assay (RIPA)}

Control non-transfected $\mathrm{CHO}$ cells or DB1cells were seeded in 6- or 12-well plates and allowed to grow for 1-3 days. They were transferred to serum-free cysteine and methionine-deficient DMEM for $1 \mathrm{~h}$ and labelled with $100 \mu \mathrm{Ci}\left[{ }^{35} \mathrm{~S}\right]$ cysteine and $\left.{ }^{35} \mathrm{~S}\right]$ methionine $\mathrm{ml}^{-1}$ (Trans ${ }^{35}$ S-label; ICN Biomedical, Costa Mesa, CA). After incubation for up to $24 \mathrm{~h}$, the labelling medium was removed and the cells were lysed in $1 \mathrm{ml}$ cold RIPA buffer $\left(50 \mathrm{mmol}\right.$ Tris- $\mathrm{HClI}^{-1}(\mathrm{pH}$ 8.0) containing $150 \mathrm{mmol}$ $\mathrm{NaClI}^{-1}, 1 \%(\mathrm{v} / \mathrm{v})$ Nonidet P-40, $0.5 \%(\mathrm{w} / \mathrm{v})$ deoxycholic acid, and $0.1 \%(\mathrm{w} / \mathrm{v}) \mathrm{SDS})$. Media and cell lysate were subjected to RIPA by addition of $10 \mu \mathrm{l}$ rabbit 38B antiserum $\mathrm{ml}^{-1}$ for $1 \mathrm{~h}$ at room temperature, followed by $12.5 \mu \mathrm{l}$ protein A beads (Pierce Chemical Co., Rockford, IL) for $1 \mathrm{~h}$ at $4^{\circ} \mathrm{C}$ to precipitate the immune complexes. Beads were washed three times with $1 \mathrm{ml}$ RIPA buffer after which bound proteins were extracted with $20 \mu \mathrm{l}$ $2 \times$ SDS-PAGE sample buffer and subjected to SDS-PAGE and autoradiography. Specific experimental conditions are given in the figure legends.

\section{Enzymatic digestion of CTGF}

DB1-derived $38 \mathrm{kDa}$ CTGF, purified by HPLC, was incubated overnight at $37^{\circ} \mathrm{C}$ with ULF essentially as described by Ball et al. (1998) except that the reaction was performed on ULF samples that had been preincubated for $1 \mathrm{~h}$ at $37^{\circ} \mathrm{C}$ in the presence or absence of $1 \mathrm{U}$ anti-thrombin III (Calbiochem, San Diego, CA).

Fig. 1. Purification of recombinant connective tissue growth factor (CTGF) isoforms from DB1 conditioned medium. (a) DB1 conditioned medium (1.2 I) was subjected to a first step of heparin affinity chromatography. This step was repeated on three additional samples of conditioned medium and fractions containing CTGF from the four experiments were pooled, diluted and applied to a TSK ${ }^{\circledR}$ heparin

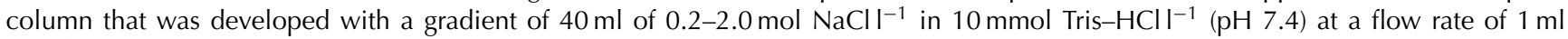
$\min ^{-1}$. Aliquots $(3 \mu \mathrm{l}$ ) of selected fractions were tested by western blot analysis using anti-CTGF(247-260) peptide antiserum (inset). (b) Heparin-purified CTGFs were diluted and applied to an Econo-Pac CM cation exchange column. The column was developed at a flow rate of $1 \mathrm{ml} \mathrm{min}^{-1}$ with a gradient of $40 \mathrm{ml}$ of $0.2-2.0 \mathrm{~mol} \mathrm{NaClI}^{-1}$ and fractions of $1 \mathrm{ml}$ were collected. The inset shows CTGFimmunoreactive proteins in aliquots of $3 \mu \mathrm{l}$ of selected fractions as assessed by western blot analysis using anti-CTGF(247-260). (c) Pooled CM fractions were adjusted to have $10 \%$ acetonitrile- $0.1 \%$ trifluoroacetic acid (TFA) and injected on to a semi-preparative $\mathrm{C}_{8}$ column $(25 \mathrm{~cm} \times 1 \mathrm{~cm})$ which was then eluted with a multilinear acetonitrile gradient in water-0.1\% TFA at a flow rate of $1 \mathrm{ml} \mathrm{min}^{-1}$. Fractions $(1 \mathrm{ml})$ that were collected 35-60 min after sample injection were tested at $1 \mu \mathrm{l}$ per well for their ability to promote 3T3 cell adhesion. The inset shows the CTGF proteins in aliquots of $1 \mu$ l of fractions 37-59 assessed by western blot analysis using anti-CTGF(247-260). 


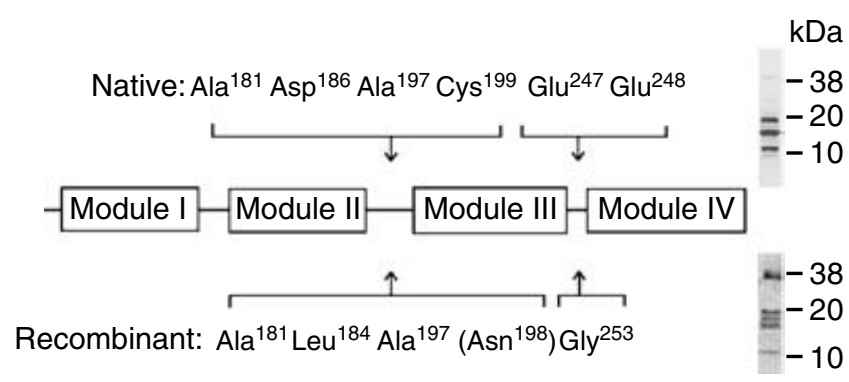

Fig. 2. Structural features of recombinant connective tissue growth factor (CTGF) isoforms. N-termini of recombinant $10 \mathrm{kDa}\left(\mathrm{Gly}^{253}\right)$, $16 \mathrm{kDa}\left(\mathrm{Ala}^{197}\right), 18 \mathrm{kDa}\left(\mathrm{Leu}^{184}\right)$ and $20 \mathrm{kDa}\left(\mathrm{Ala}^{181}\right)$ CTGFs purified from DB1 conditioned medium and their relationship to the $\mathrm{N}$-termini of native $10 \mathrm{kDa}\left(\mathrm{Glu}^{247}, \mathrm{Glu}^{248}\right), 16 \mathrm{kDa}\left(\mathrm{Ala}^{197}, \mathrm{Cys}^{199}\right)$ or $18-20 \mathrm{kDa}\left(\mathrm{Asp}^{186}\right)$ CTGFs in pig uterine secretions (Brigstock et al., 1997; Ball et al., 1998) and $19 \mathrm{kDa}\left(\mathrm{Ala}^{181}\right)$ CTGF in bovine endothelial cell conditioned medium (Boes et al., 1999). The western blots show that although the lower molecular mass forms of CTGF are readily detectable in both uterine secretions (upper blot) and DB1 medium (lower blot), the $38 \mathrm{kDa}$ CTGF protein is only appreciably present in the recombinant system; sequence analysis of this latter protein was unsuccessful and was probably due to a blocked $\mathrm{N}$-terminus. The recombinant CTGF isoform denoted with its first residue in parentheses $\left(\mathrm{Asn}^{198}\right)$ was produced by thrombin digestion of the $38 \mathrm{kDa}$ CTGF protein.

In addition, the various CTGF isoforms were treated for $2.5 \mathrm{~h}$ at $37^{\circ} \mathrm{C}$ with 0.2 or $2.0 \mathrm{U}$ kallikrein (Sigma Chemical Co., St Louis MO) or overnight at $37^{\circ} \mathrm{C}$ with $20 \mathrm{U}$ thrombin (Roche Molecular Biochemicals, Indianapolis, IN). Samples were assessed by western blot analysis. Specific experimental details are given in the figure legends.

\section{Results}

\section{CTGF purification, isolation and biological activity}

In preliminary experiments, it was found that export of recombinant CTGF by stably transfected wild-type $\mathrm{CHO}$ $\mathrm{K} 1$ cells into the medium was significantly enhanced in the presence of $100 \mu \mathrm{g}$ heparin $\mathrm{ml}^{-1}$ (data not shown), an observation that is consistent with the previously reported ability of CTGF and CYR61 to associate with cell surfaces via heparin sulphate proteoglycans (Yang and Lau, 1991; Kireeva et al., 1997). Since heparin introduced undefined contaminants into the preparation, we next stably transfected CTGF cDNA into the CHO 745 mutant cell line that lacks xylosyl transferase and exhibits heparin sulphate and chondroitin sulphate deficiency (Esko et al., 1985). This was expected to facilitate deposition of CTGF into the conditioned medium without the need for addition of heparin. Indeed, western blot analysis of the conditioned medium from 52 colonies of transfected $\mathrm{CHO} 745$ cells revealed that 13 colonies were positive for $38 \mathrm{kDa}$ CTGF in the absence of added heparin and that the amount of CTGF released was substantially greater than that seen in transfected parental $\mathrm{CHO}$ cells (data not shown). In addition, the conditioned media from eight of the CTGF-positive colonies also contained lower molecular mass (10-20 kDa) forms of CTGF (data not shown). As the antibody used in this experiment was directed towards the C-terminus of CTGF (residues 247-260), these findings indicate that the recombinant $38 \mathrm{kDa}$ CTGF was subject to limited proteolysis as observed in vivo (Brigstock et al., 1997; Ball et al., 1998 ) and that the proteins were probably C-terminal fragments of CTGF. One colony, termed DB1, which exhibited the highest CTGF production was selected for mass-scale culture to characterize and purify all CTGF isoforms.

Heparin affinity chromatography of DB1 conditioned medium demonstrated that all CTGF isoforms would bind heparin and required approximately $0.8 \mathrm{~mol} \mathrm{NaCl} \mathrm{I}^{-1}$ for elution from heparin beads (Fig. 1a), as shown for native CTGF isoforms by Brigstock et al. (1997) and Ball et al. (1998). The relative abundance of the purified CTGF proteins was 16-20 kDa CTGF $>30 \mathrm{kDa}$ CTGF $>10 \mathrm{kDa}$ CTGF and did not change in subsequent purification steps. Since the various CTGF isoforms did not demonstrate differential heparin-binding properties and could not therefore be individually studied, they were coeluted and subjected to cation exchange chromatography (Fig. 1b). In this step, salt gradient elution of the column allowed for the successive elution of $38 \mathrm{kDa}$ CTGF, 16-20 kDa CTGF and $10 \mathrm{kDa}$ CTGF demonstrating that the net negative charge of $10 \mathrm{kDa} C T G F>16-20 \mathrm{kDa}$ CTGF $>38 \mathrm{kDa}$ CTGF. $\mathrm{C}_{8}$ reverse-phase HPLC resulted in the sequential elution of $10 \mathrm{kDa} C T G F$ at $37-38.5 \mathrm{~min}$, 16-20 kDa CTGF at 39-47 min, and $38 \mathrm{kDa}$ CTGF at 5059 min (Fig. 1c), allowing the isolation of each isoform and showing that the net hydrophobicity of $38 \mathrm{kDa}$ CTGF $>16-20 \mathrm{kDa}$ CTGF $>10 \mathrm{kDa}$ CTGF. When nontissue culture ELISA plates were precoated with fixed aliquots of each fraction, each CTGF isoform promoted the adhesion of Balb/c 3T3 cells to the plastic wells (Fig. 1c). These data are consistent with previous reports showing that $38 \mathrm{kDa}$ CTGF can promote cell adhesion (Babic et al., 1999; Jedsadayanmata et al., 1999; Lau and Lam, 1999; C. C. Chen et al., 2001; Schober et al., 2002) and further showed that the lower molecular mass CTGF isoforms contain sufficient structural information to support this process. Yields of the HPLC-purified proteins per litre of conditioned medium were approximately $1 \mathrm{mg} 16-20 \mathrm{kDa}$ CTGF, $0.5 \mathrm{mg} 38 \mathrm{kDa}$ CTGF, and $0.1 \mathrm{mg}$ $10 \mathrm{kDa}$ CTGF. CTGF constituted $2.1 \%$ of the total protein in the conditioned medium, with $>90 \%$ recovery after heparin affinity and cation exchange chromatographies and approximately $62 \%$ recovery after reverse-phase HPLC (data not shown). No high molecular mass CTGF proteins (for example, $>38 \mathrm{kDa}$ ) were detected in the conditioned medium before or after purification. 
(a)
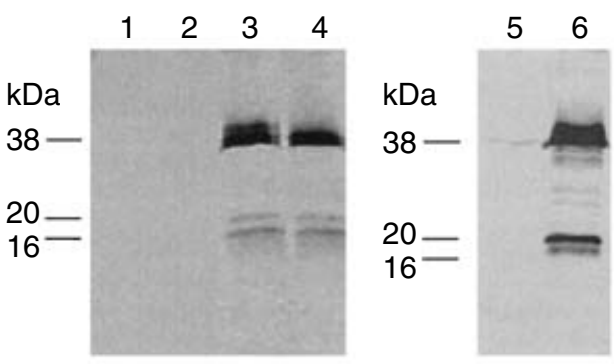

(b)
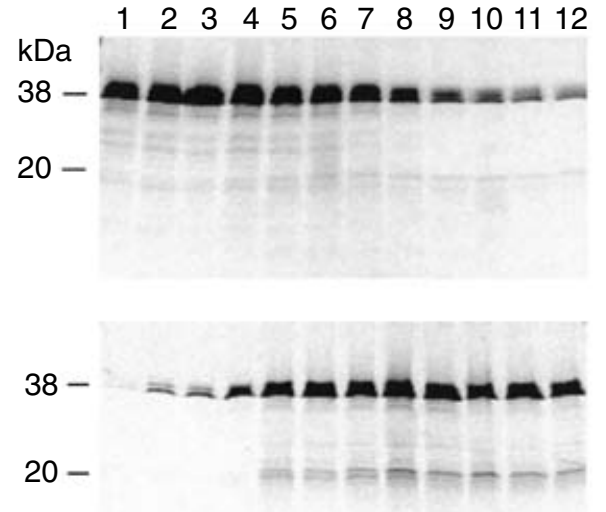

(c)

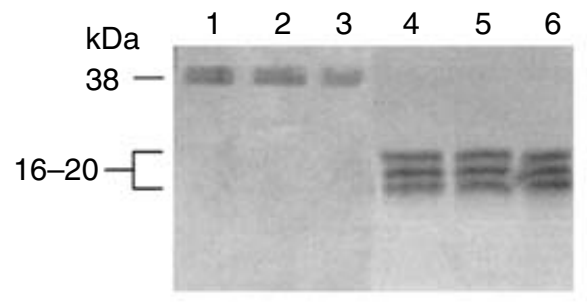

Fig. 3. Connective tissue growth factor (CTGF) glycosylation, kinetics of release and stability. (a) Control non-transfected Chinese hamster ovary $(\mathrm{CHO}) 745$ cells (lanes 1,2$)$ or DB1 cells (lanes 3-6) were seeded at $1.6 \times 10^{5}$ cells per well in a six-well plate for $24 \mathrm{~h}$ in $2 \mathrm{ml}$ Dulbecco's modified Eagle's medium (DMEM)$10 \%$ fetal bovine serum (FBS) after which the medium was changed to $1 \mathrm{ml}$ cysteine and methionine-free DMEM containing $100 \mu \mathrm{Ci}\left[{ }^{35} \mathrm{~S}\right]$ cysteine and $\left[{ }^{35} \mathrm{~S}\right]$ methionine $\mathrm{ml}^{-1}$. Wells received either no treatment (lanes $1,3,5,6$ ) or $5 \mu \mathrm{g}$ tunicamycin $\mathrm{ml}^{-1}$ (lanes 2,4 ) for the next $24 \mathrm{~h}$ at $37^{\circ} \mathrm{C}$, after which medium was collected (lanes 1-4) or the cells were lysed with radioimmunoprecipitation assay buffer (lanes 5, 6). Samples were incubated with $10 \mu \mathrm{l}$ preimmune serum (lane 5) or $10 \mu \mathrm{l}$ anti$38 \mathrm{kDa}$ CTGF antiserum (rabbit 38B) (lanes 1-4, 6) and immunoprecipitates were analysed on $18 \%$ SDS-PAGE gels under reducing conditions, dried and exposed to X-ray film for $2 \mathrm{~h}$. (b) DB1 cells were seeded at $8 \times 10^{4}$ cells per well in $1 \mathrm{ml}$ DMEM$10 \%$ FBS in a 12-well plate for 3 days. The medium in each well was then replaced for $1 \mathrm{~h}$ with $1 \mathrm{ml}$ cysteine and methionine-free DMEM, which was then replaced with $0.5 \mathrm{ml}$ of the same medium containing $100 \mu \mathrm{Ci}\left[{ }^{35} \mathrm{~S}\right.$ cysteine and $\left[{ }^{35} \mathrm{~S}\right.$ ] methionine $\mathrm{ml}^{-1}$ for $15 \mathrm{~min}$. The labelling medium was then removed; the cells were washed twice with PBS, and $0.5 \mathrm{ml}$ DMEM-10\% FBS was then

\section{Structural characterization of CTGF isoforms}

No amino acid sequence was obtained for $38 \mathrm{kDa}$ CTGF indicating that the protein had a blocked $\mathrm{N}$ terminus. N-terminal analysis of the lower molecular mass CTGF isoforms revealed that they commenced either between modules 2 and 3 with $\mathrm{N}$-termini at $\mathrm{Ala}^{181}$ (20 kDa CTGF), Leu ${ }^{184}$ (18 kDa CTGF) or Ala ${ }^{197}$ (16 kDa CTGF) or between modules 3 and 4 with an $\mathrm{N}$-terminus at Gly ${ }^{253}$ (10 kDa CTGF). As shown (Fig. 2), the 10-20 kDa CTGFs were structurally identical or very similar to the various CTGF isoforms identified in pig uterine fluids (Brigstock et al., 1997; Ball et al., 1998) or cultured bovine endothelial cells (Boes et al., 1999).

\section{Kinetics of CTGF release and CTGF glycosylation}

Antiserum raised against purified $38 \mathrm{kDa}$ CTGF was able to immunoprecipitate the $16-20 \mathrm{kDa}$ and $38 \mathrm{kDa}$ isoforms of CTGF produced by DB1 cells whereas preimmune serum was ineffective (Fig. 3a). No immunoreactive CTGF proteins were apparent in non-transfected $\mathrm{CHO} 745$ cells, showing production of endogenous CTGF was not detectable under normal circumstances (Fig. 3a). DB1-derived $38 \mathrm{kDa}$ CTGF occurred as a protein triplet, the upper band of which was absent after incubation of the cells with tunicamycin, an inhibitor of $\mathrm{N}$-linked glycosylation (Fig. 3a). However, tunicamycin had no effect on the electrophoretic mobility of 1620 kDa CTGFs (Fig. 3a).

Pulse chase analysis of metabolically labelled CTGF showed very high concentration of $38 \mathrm{kDa}$ CTGF in cell lysates for the first $60 \mathrm{~min}$ after $15 \mathrm{~min}$ of labelling, with progressively diminishing concentration up to $6 \mathrm{~h}$ (Fig. 3b). The $38 \mathrm{kDa}$ CTGF was detectable in the medium as early as $5 \mathrm{~min}$ after synthesis although secreted amounts remained relatively low for the first $20 \mathrm{~min}$, increased appreciably between 45 and $60 \mathrm{~min}$, and reached a plateau between $90 \mathrm{~min}$ and $6 \mathrm{~h}$. Collectively these data show that $38 \mathrm{kDa}$ CTGF was secreted very efficiently from the cells and that $>90 \%$ of the protein had been exported from the cells within $3 \mathrm{~h}$ of synthesis. The $20 \mathrm{kDa}$ CTGF was observed in both cell lysates and conditioned medium 45 min after the labelling period and its concentration was correlated with those of $38 \mathrm{kDa}$ CTGF (Fig. 3b). At $37^{\circ} \mathrm{C}$ in cell-free culture medium, both

added to the wells for $0,5,10,20,45,60,90,120,180,240$, 300 or $360 \mathrm{~min}$ (lanes 1-12, respectively). Cell lysates (upper panel) and media (lower panel) were harvested from each well and subjected to immunoprecipitation using rabbit 38B antiserum. Samples were run under reducing conditions on $18 \%$ SDS-PAGE gels, which were then dried and exposed to X-ray film for $16 \mathrm{~h}$. (c) Purified $38 \mathrm{kDa}$ CTGF (lanes 1-3) or 16-20 kDa CTGF (lanes 4-6) were incubated in culture medium at $37^{\circ} \mathrm{C}$ for 1 day (lanes $1,4), 2$ days (lanes 2,5) or 3 days (lanes 3,6) and then subjected to SDS-PAGE and assessed by western blot analysis using antiCTGF(247-260). 
(a)
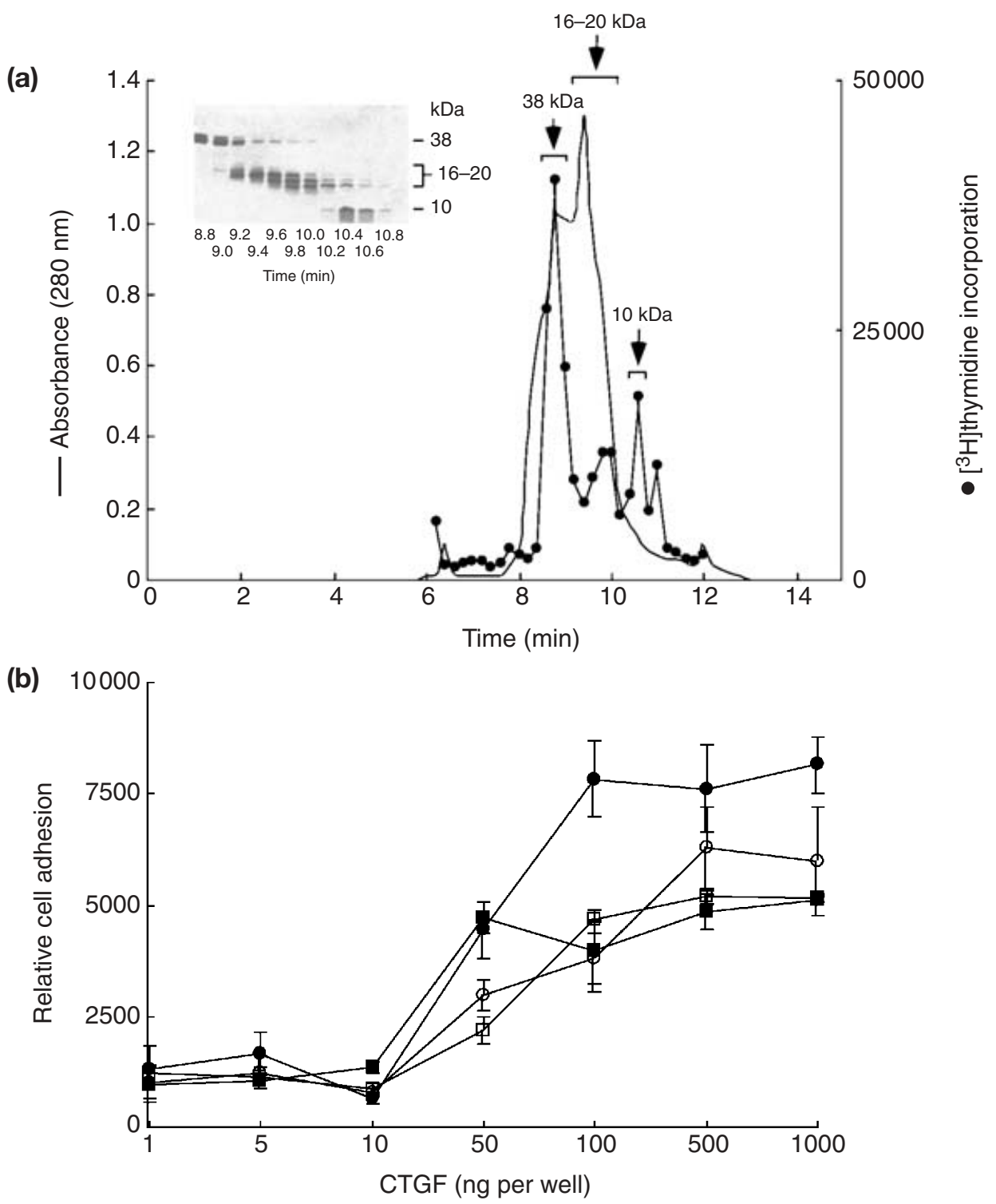

(c)

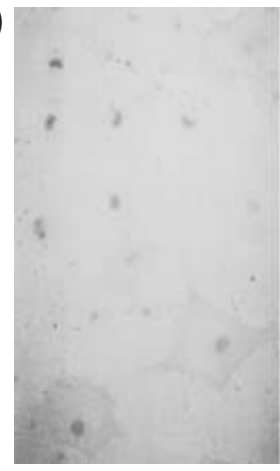

No addition

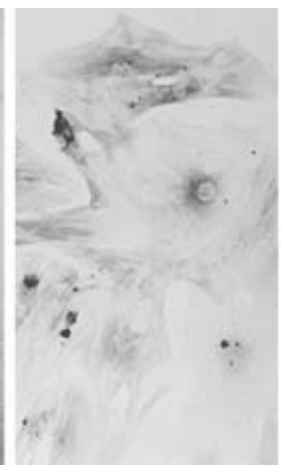

$10 \mathrm{kDa}$

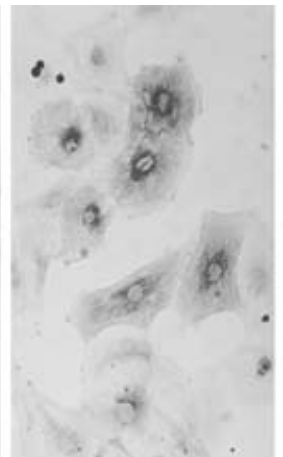

16-20 kDa

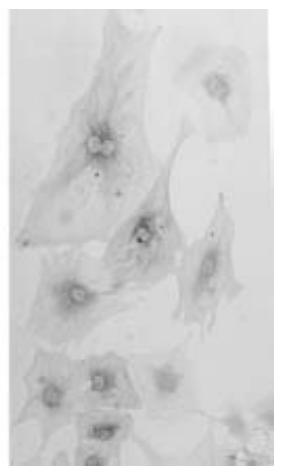

$38 \mathrm{kDa}$

Fig. 4. Biological activities of recombinant connective tissue growth factor (CTGF) proteins. (a) Heparin-purified CTGFs $(100 \mu \mathrm{l})$ were injected on to a Biosep S-2000 column that was then eluted with PBS containing $0.5 \mathrm{~mol} \mathrm{NaCl}{ }^{-1}$ at a flow rate $0.5 \mathrm{ml} \mathrm{min}{ }^{-1}$. Fractions $(100 \mu \mathrm{l})$ were collected and tested at $5 \mu \mathrm{l}$ per well for their ability to stimulate $\left[{ }^{3} \mathrm{H}\right]$ thymidine incorporation ( in 3 T3 cells and at $9 \mu \mathrm{l}$ per lane for detection of CTGF proteins by SDS-PAGE and western blot analysis using anti-CTGF(247-260). (b) Dose-dependent stimulation of 3T3 cell adhesion 
purified 38 kDa CTGF and 16-20 kDa CTGFs were stable for at least $72 \mathrm{~h}$ (Fig. 3c). These data support the notion that the cell-associated proteases were responsible for CTGF processing and that various CTGF isoforms in conditioned medium at 3 days (Fig. 1) were not generated by an intrinsic instability of $38 \mathrm{kDa}$ CTGF over the culture period of 3 days.

\section{Biological characterization of CTGF}

Previously, $38 \mathrm{kDa}$ CTGF has been shown to regulate various cell functions including stimulation of cell adhesion (Yang and Lau, 1991; Kireeva et al., 1997), aSMA production (Frazier et al., 1996) and mitosis (Bradham et al., 1991; Frazier et al., 1996), the last of which is also stimulated by C-terminal $10 \mathrm{kDa}$ fragments of CTGF (Brigstock et al., 1997). Each isoform was assessed in several biological assays to verify that these properties were preserved in DB1-derived $38 \mathrm{kDa}$ CTGF and to investigate the bioactivity of 10-20 kDa CTGFs.

When subjected to size-exclusion chromatography, three peaks of Balb/c 3T3 cell mitogenic activity were eluted from the column that were correlated with the successive elution of $38 \mathrm{kDa}, 16-20 \mathrm{kDa}$, and $10 \mathrm{kDa}$ CTGF as determined by western blot analysis (Fig. 4a). As similar data were obtained with respect to the ability of the individual isoforms to stimulate Balb/c 3T3 cell adhesion after purification by reverse-phase HPLC (Fig. 1c), specific activity curves were generated to assess the relative ability of each isoform to promote cell adhesion. All isoforms exhibited comparable activity, with dose-dependent stimulation of cell adhesion at CTGF coating doses of 10-100 ng per well (Fig. 4b). Higher maximal cell adhesion was achieved by $100-$ $1000 \mathrm{ng} 10 \mathrm{kDa}$ CTGF per well compared with the same doses of the other CTGF isoforms.

$\alpha S M A$ production in response to each CTGF isoform was assessed in vitro using immunocytochemical staining of primary cultures of rat corneal epithelial cells. After $24 \mathrm{~h}$ exposure to $100-400 \mathrm{ng}$ each isoform $\mathrm{ml}^{-1}$, there was profound induction of $\alpha \mathrm{SMA}$ in the cells, showing that the various CTGF proteins were similarly effective at inducing transdifferentiation of epithelial cells into myofibroblastic-like cells (Fig. 4c). As subcutaneous injection of $38 \mathrm{kDa}$ CTGF stimulates persistent fibrosis as assessed by increased frequency of $\alpha$ SMA-positive myofibroblastic cells (Mori et al., 1999), each purified CTGF isoform was tested for its effect on $\alpha$ SMA production in vivo using the same approach. Neonatal mice received daily subcutaneous administration of $340 \mathrm{ng}$ CTGF consecutively for 7 days and were killed 14 days after the last injection. Compared with control animals, which demonstrated approx-

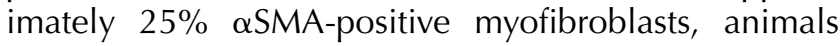
receiving $10 \mathrm{kDa}, 16-20 \mathrm{kDa}$ or $38 \mathrm{kDa}$ CTGF demonstrated, respectively, $76 \%, 68 \%$ or $45 \%$ myofibroblasts (data not shown). These data showed that the recombinant CTGF was active in vivo in a wellestablished model of persistent fibrosis and that the C-terminus of CTGF contained sufficient information to elicit this effect.

\section{CTGF processing}

It was shown previously that pig uterine secretions contain CTGF proteases that rapidly degrade $38 \mathrm{kDa}$ CTGF into lower molecular mass forms (Ball et al., 1998). DB1-derived $38 \mathrm{kDa}$ CTGF was incubated with uterine fluids for up to $6 \mathrm{~h}$ to verify that it was similarly susceptible. Partial degradation of $38 \mathrm{kDa}$ to $20 \mathrm{kDa}$ CTGF was observed in the presence of uterine fluids after exposure for $30 \mathrm{~min}$, and complete disappearance of the $38 \mathrm{kDa}$ protein was observed after $6 \mathrm{~h}$ of treatment (Fig. 5a). In contrast, no degradation was observed over this period when $38 \mathrm{kDa}$ CTGF was incubated in PBS (Fig. 5a). The $20 \mathrm{kDa}$ C-terminal product of this reaction was completely stable (Fig. 5a), as reported by Ball et al. (1998). ULF-mediated degradation of CTGF was inhibited by anti-thrombin III (Fig. 5b) whereas thrombin was effective in proteolysing both $38 \mathrm{kDa}$ CTGF to 16$28 \mathrm{kDa}$ CTGF and purified 18-20 kDa CTGFs to $16 \mathrm{kDa}$ CTGF (Fig. 5c). When the incubation of $38 \mathrm{kDa}$ CTGF with thrombin was repeated on a semi-preparative scale, the resulting $16 \mathrm{kDa}$ product was found to have an $\mathrm{N}$ terminus at $\mathrm{Asp}^{198}$ corresponding to one residue fewer than the $16 \mathrm{kDa}$ isoform present in DB1-conditioned medium or pig uterine fluids (see Fig. 2). In addition, the effect of kallikrein on CTGF degradation was tested in view of the current interest in this enzyme in pig reproductive tract function (Vonnahme et al., 1999; Geisert et al., 2001). At $0.02 \mathrm{U}$, kallikrein degraded $18 \mathrm{kDa}$ CTGF and $38 \mathrm{kDa}$ CTGF with the concomitant production of a $12 \mathrm{kDa}$ isoform, whereas at $2 \mathrm{U}$ kallikrein all of the CTGF isoforms were degraded yielding hitherto unreported immunoreactive proteins of 9, 11 and $15 \mathrm{kDa}$ (Fig. 5c). (DMEM) $-10 \%$ fetal bovine serum (FBS). The cells were then grown for 2 days in serum-free DMEM containing insulin, transferrin and sodium selenite. This medium was then replenished for $24 \mathrm{~h}$ with either no further addition or with addition of $400 \mathrm{ng}$ each CTGF isoform $\mathrm{ml}^{-1}$. Alpha smooth muscle actin $(\alpha \mathrm{SMA})$ was detected by immunohistochemistry and nuclei were counterstained with haematoxylin. $\alpha$ SMA fibres are clearly apparent in CTGF-treated cells. Comparable data were obtained with $100 \mathrm{ng} \mathrm{CTGFs} \mathrm{ml}^{-1}$ (data not shown). 
(a)

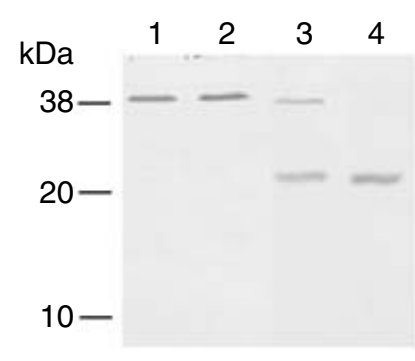

(b)

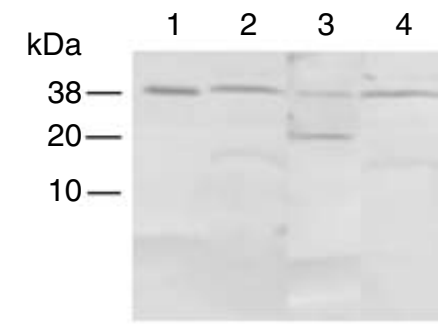

(c)

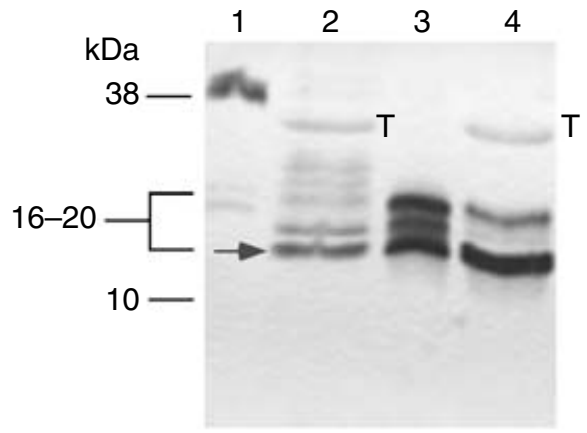

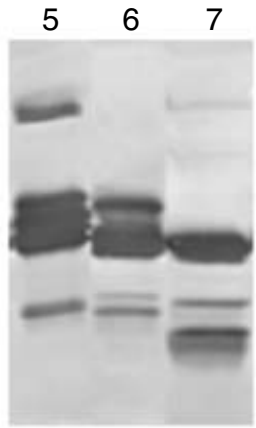

Fig. 5. Enzymatic degradation of uterine luminal fluid (ULF). (a) The $38 \mathrm{kDa}$ connective tissue growth factor (CTGF) was incubated in $20 \mu \mathrm{l}$ PBS (lanes 1,2) or $19 \mu \mathrm{l} \mathrm{PBS}$ plus $1 \mu \mathrm{l}$ ULF (lanes 3, 4) for $30 \mathrm{~min}$ (lanes 1,3 ) or $6 \mathrm{~h}$ (lanes 2,4 ) at $37^{\circ} \mathrm{C}$. Samples were assessed by western blot analysis using anti-CTGF(247-260) antiserum. (b) The $38 \mathrm{kDa}$ CTGF was incubated overnight at $37^{\circ} \mathrm{C}$ in a final reaction volume of $20 \mu \mathrm{l}$ in PBS (lanes 1,2) or PBS with pig uterine fluid (lanes 3, 4), after $1 \mathrm{~h}$ preincubation alone (lanes 1,3) or with $1 \mathrm{U}$ anti-thrombin III (lanes 2, 4). Samples were assessed by western blot analysis using anti-CTGF(247-260) antiserum. (c) Purified 38 kDa CTGF (lanes 1, 2), 16-20 kDa CTGF (lanes 3, 4), or all CTGF isoforms (lanes $5-7)$ were incubated overnight at $37^{\circ} \mathrm{C}$ alone (lanes 1,3 ) or in the presence of $20 \mathrm{U}$ thrombin (lanes 2,4), or for $2.5 \mathrm{~h}$ at $37^{\circ} \mathrm{C}$ alone (lane 5) or in the presence $0.2 \mathrm{U}$ kallikrein (lane 6) or $2.0 \mathrm{U}$ kallikrein (lane 7). The products of the reaction were assessed by SDS-PAGE and western blot analysis using anti-CTGF(247-260). The arrow shows a CTGF isoform that was obtained from a comparable preparative-scale digestion and found to commence at $\mathrm{Asn}^{198}$ (see Fig. 2). The proteins marked with a ' $\mathrm{T}$ ' are thrombin that was detected non-specifically in the reaction mixture.

\section{Discussion}

Although CTGF was discovered more than a decade ago, detailed structural and functional studies of this protein have not been performed. Although the modular structure of CTGF has been indicative of potentially important domains within the molecule, the biological role of these domains has not been determined. CTGF interacts with IGF-I (Kim et al., 1997) and promotes cell adhesion (Babic et al., 1999; Jedsadayanmata et al., 1999; Lau and Lam, 1999; C. C. Chen et al., 2001; Schober et al., 2002) and these properties are consistent with the proposed presence of IGF binding and cell attachment motifs in modules 1 and 3 respectively (Bork, 1993). The serendipitous discovery of heparin-binding biologically active C-terminal fragments of CTGF in uterine fluids provided a new lead for CTGF structurefunction studies in that putative domains that are heparin- binding and receptor-binding were mapped to the C-terminal 102 residues (Brigstock et al., 1997). Unfortunately, the difficulty of isolating these proteins from their native sources has severely hampered their further study. In addition, there are virtually no convenient sources of the native $38 \mathrm{kDa}$ CTGF protein that are amenable for large-scale purification. For example, although CTGF is produced by many cell types in culture (Moussad and Brigstock, 2000), scale-up of these in vitro systems has not been reported and would be unlikely readily to generate acceptable yields without considerable time and expense.

CTGF contains 38 cysteine residues (10\% by mass), which are presumed to form intrachain disulphide bridges necessary for its modular structure (Bork, 1993). It is critical that this very complex protein structure be faithfully reproduced in recombinant expression systems. Although post-translational modifications of CTGF have 
not been widely studied, human CTGF appears to be $N$-linked glycosylated (Yang, et al., 1998) although this modification does not appear to occur in CTGF of other species. In addition, $38 \mathrm{kDa}$ CTGF is highly susceptible to limited proteolysis, yielding $10-20 \mathrm{kDa}$ CTGF isoforms comprising modules 3 and 4 or module 4 alone (Brigstock et al., 1997; Ball et al., 1998; Steffen et al., 1998; Yang et al., 1998; Williams et al., 2000). It is unclear whether these proteins can be faithfully generated by direct cloning and expression of the corresponding cDNA or whether their cleavage from the $38 \mathrm{kDa}$ CTGF protein is a prerequisite for their structural and functional integrity.

In the present study, we have developed a recombinant CTGF expression system in a mutant $\mathrm{CHO}$ cell line. After transfection of a full-length human CTGF cDNA into the cells, $38 \mathrm{kDa}$ CTGF was produced that underwent limited proteolysis yielding 10-20 kDa C-terminal isoforms that were virtually indistinguishable from those found in utero and which exhibit a comparable biological dose-response and a repertoire of biological actions as full-length CTGF. As the mass of $38 \mathrm{kDa}$ CTGF was decreased in the presence of tunicamycin, it was concluded that the recombinant protein was glycosylated as is predicted from the presence of potential $\mathrm{N}$-glycosylation sites at $\mathrm{Asp}^{28}$ and $\mathrm{Asp}^{225}$. However, the decrease in mass of $38 \mathrm{kDa}$ CTGF was modest indicating that the $\mathrm{N}$-glycan groups in $38 \mathrm{kDa}$ CTGF are relatively small. As tunicamycin had no effect on 16-20kDa CTGFs that contained $\mathrm{Asp}^{225}$ but not $\mathrm{Asp}^{28}$, these data collectively indicate that Asp $^{28}$ is preferentially utilized for glycosylation or that $\mathrm{Asp}^{225}$ was subsequently deglycosylated. As some 38 kDa CTGF moieties were not affected by tunicamycin, it may be concluded that they were either slightly truncated at the $\mathrm{N}$-terminus and lacked $\mathrm{Asp}^{28}$ or represented authentic non-glycosylated forms of the protein.

Previously, an attempt to express $38 \mathrm{kDa}$ CTGF in E. coli was apparently successful in producing an immunoreactive protein but no biological activity was associated with the recombinant protein (Bradham et al., 1991). A more successful strategy has been to produce recombinant baculoviruses allowing for the expression in infected insect cells of human CTGF (Frazier et al., 1996; Y. Chen et al., 2001), mouse CTGF (Kireeva et al., 1997) or FLAG-tagged CTGF (Yang et al., 1998; Fan and Karnovsky, 2000). The 38 kDa CTGF produced in this manner has been purified from serum-free conditioned medium using single steps of Sepharose S chromatography (Kireeva et al., 1997), heparin-affinity chromatography (Frazier et al., 1996) or anti-FLAG antibody (Yang et al., 1998), or by sequential steps of HS20 sulphopropyl and CM-20 cation exchange chromatography (Y. Chen et al., 2001) or Q Sepharose chromatography followed by anti-FLAG affinity chromatography (Fan and Karnovsky, 2000). In some instances, the purity, structure, secondary modifications, and specific activity of the end-product have often not been rigorously analysed and, importantly, proteolytic processing of CTGF by insect cells has yet to be reported. An alternative approach has been to use a CMV-driven mammalian expression plasmid to stably overexpress CTGF cDNA in HeLa cells. CTGF produced in this manner was isolated from serum-free conditioned medium by ammonium sulphate precipitation, heparin affinity chromatography, and anti-CTGF affinity chromatography (Nishida et al., 1998). Other mammalian cell CTGF expression systems have involved production of FLAGtagged CTGF in 293T cells (Inoki et al., 2002) or a CTGFV5 fusion protein in mesangial cells (Wahab et al., 2001) from which CTGF was purified using anti-FLAG or antiV5 affinity chromatography, respectively. In all cases, the $38 \mathrm{kDa}$ CTGF molecule appears to be the sole form of the protein produced.

The results of the present study show that the DB1 expression system is a valuable tool for preparativescale production and isolation of all CTGF isoforms identified to date. Purification of recombinant CTGFs was facilitated by the lack of expression of heparan sulphate proteoglycans by DB1 cells, which allowed for highly efficient export of CTGF into defined serum-free medium. Once conditioned medium was collected from DB1 cells, the relative proportion of the CTGF isoforms remained unchanged through the chromatographic steps showing that they were intrinsically very stable. This stability was also apparent when purified $18-20 \mathrm{kDa}$ or $38 \mathrm{kDa}$ CTGFs were incubated at $37^{\circ} \mathrm{C}$ for 3 days. However, $18-20 \mathrm{kDa}$ or $38 \mathrm{kDa}$ CTGFs were rapidly processed to lower molecular mass isoforms by DB1 cells or after exposure to uterine fluids, kallikrein or thrombin, the last of which converted $38 \mathrm{kDa}$ CTGF to a $16 \mathrm{kDa}$ isoform that contained a single residue fewer than $16 \mathrm{kDa}$ CTGF produced by the pig uterus (Ball et al., 1998) or DB1 cells.

It was shown previously that CTGF protease concentrations in pig ULF were highly correlated with the concentrations of 10-20 kDa CTGF and were detectable at relatively earlier stages of pregnancy than during the oestrous cycle (day 11 versus day 14, respectively) (Ball et al., 1998). The present study shows that the CTGF-degrading activity in ULF is anti-thrombin IIIsensitive, which implicates involvement of one or more serine proteases of the blood coagulation system such as thrombin, plasmin, kallikrein or protease factors IXa, Xa, Xia and XIla. When thrombin and kallikrein were tested directly in this regard, each enzyme was able to catalyse CTGF proteolysis, indicating that they are possible candidates in utero for this role. Aside from their role in blood coagulation in utero, thrombin regulates endometrial stromal cell proliferation and myometrial contraction (Arena et al., 1996; Asselin and Fortier, 1996; Elovitz et al., 2000), whereas kallikrein regulates embryo implantation and maintenance of utero-placental blood flow (Valdes et al., 1998, 2001; 
Vonnahme et al., 1999). More recently, kallikrein has been implicated in proteolysis of IGF binding proteins during the oestrous cycle and early pregnancy in pigs (Geisert et al., 2001), an observation that may be relevant to our current studies since CTGF binds IGF-I and IGF-II, albeit weakly (Kim et al., 1997). Although the potential importance of kallikrein and thrombin in CTGF processing has not been documented previously, it is likely that these or similar serine proteases account for the production of low molecular mass CTGFs in utero and in the DB1 cell culture system. Thrombin is also a direct stimulator of CTGF expression in several systems (Chambers et al., 2000; Pendurthi et al., 2000; Howell et al., 2001) indicating that it exerts control over CTGF production during transcription and after translation. As the CTGF isoforms produced by DB1 cells are readily detectable by purification or immunoprecipitation, this culture system will greatly facilitate studies designed to identify the specific enzymes responsible for CTGF processing.

Although the degree of CTGF processing is likely to affect the repertoire of interactions of CTGF with other binding moieties, our data indicate that important functional domains reside in module 4 since isoforms containing only this module appear to exhibit at least some of the biological activities as fulllength CTGF. As such, CTGF isoforms that comprise essentially module 4 will be extremely useful ligands with which to study CTGF binding interactions with target cells since other binding domains are absent. However, it should be emphasized that this does not rule out the possibility that modules 1, 2 or 3, either individually or collectively, also contain functional domains that contribute to the overall activity of a given CTGF isoform. A case in point is that while $10 \mathrm{kDa}$ CTGF is effective at promoting cell adhesion, it is also possible that the putative cell attachment motif in module 3 also contributes to the cell adhesion properties exhibited by $16-20 \mathrm{kDa}$ or $38 \mathrm{kDa}$ CTGFs. Nonetheless it appears that module 4 contains one or more functional domains that account for its ability to bind to heparin and to stimulate diverse cell functions including adhesion, mitosis and $\alpha S M A$ production. These data support the conclusions of previous studies that indicate that native $10 \mathrm{kDa}$ CTGF is mitogenic and heparin-binding and that synthetic peptides corresponding to residues 247-260, 274-286 and 305-328 are strongly heparin-binding (Brigstock, et al., 1997). These data indicate that module 4 is fundamentally important for CTGF function and are supported by the finding that the related protein, CYR61, lost its ability to bind to heparin and did not promote cell adhesion after mutagenesis of two putative heparinbinding domains in module 4 (Chen et al., 2000). On the other hand, Cop1, a CTGF-related protein that comprises modules 1-3 but lacks module 4 entirely, exhibits a broad range of activities including stimulation of integrin-mediated osteoblast cell adhesion (Kumar et al.,
1999), inhibition of osteocalcin production by osteoblasts (Kumar et al., 1999), and growth suppression of vascular smooth muscle cells or transformed fibroblasts (Zhang et al., 1998; Delmolino et al., 2001). Thus the net activity of a given CTGF family member probably reflects the unique structural properties of each isoform and, possibly, functional overlap or redundancy between discrete regions of the protein.

In conclusion, the development of the DB1 cell line represents an important step in providing preparative quantities of the various CTGF isoforms that were identified in utero several years ago but which previously have not been produced recombinantly. In addition, this cell line will serve as a useful model for studying limited proteolysis of the CTGF protein. Whereas the individual modules of CTGF appear very stable, the regions between either modules 2 and 3 or modules 3 and 4 are highly susceptible to proteolytic cleavage, a phenomenon that is probably attributable, at least in uterine fluids, to serine proteases such as thrombin or kallikrein. Moreover, the resulting C-terminal fragments exhibit comparable activities to the intact CTGF protein. Future studies will be focused on mapping the domains in the C-terminus of CTGF that are critical for its functionality, establishing the potential co-operativity of these domains with other regions of the CTGF molecule, and understanding the relationship between CTGF proteolysis, bioavailability, and mode of action.

The authors thank C. L. Owens (Case Western Reserve University, Cleveland, $\mathrm{OH}$ ) for assistance with protein sequencing. This work was supported by USDA grant 98-35206-6430 awarded to D. R. Brigstock and by a research award from FibroGen Inc in which D. R. Brigstock has an equity interest. D. K. Ball was supported in part by NIH grant 2 T32 CA09498-11 awarded to F. M. Robertson.

\section{References}

Arena CS, Quirk SM, Zhang YQ and Henrikson KP (1996) Rat uterine stromal cells: thrombin receptor and growth stimulation by thrombin Endocrinology 137 3744-3749

Asselin E and Fortier MA (1996) Influence of thrombin on proliferation and prostaglandin production in cultured bovine endometrial cells Journal of Cellular Physiology 168 600-607

Babic AM, Chen CC and Lau LF (1999) Fisp12/mouse connective tissue growth factor mediates endothelial cell adhesion and migration through integrin $\alpha \vee \beta 3$, promotes endothelial cell survival, and induces angiogenesis in vivo. Molecular and Cellular Biology 19 2958-2966

Ball DK, Surveyor GA, Diehl JR, Steffen CL, Uzumcu M, Mirando MA and Brigstock DR (1998) Characterization of 16- to 20-kilodalton ( $\mathrm{kDa}$ ) connective tissue growth factors (CTGFs) and demonstration of proteolytic activity for 38-kDa CTGF in pig uterine luminal flushings Biology of Reproduction 59 828-835

Blom IE, van Dijk AJ, Wieten L et al. (2001) In vitro evidence for differential involvement of CTGF, TGFbeta, and PDGF-BB in mesangial response to injury Nephrology, Dialysis, Transplantation 16 1139-1148

Boes M, Dake BL, Booth BA, Erondu NE, Oh Y, Hwa V, Rosenfeld R and Bar RS (1999) Connective tissue growth factor (IGFBP-rP2) expression and regulation in cultured bovine endothelial cells Endocrinology $\mathbf{1 4 0}$ 1575-1580 
Bork P (1993) The modular architecture of a new family of growth regulators related to connective tissue growth factor FEBS Letters 327 125-130

Bradham DM, Igarashi A, Potter RL and Grotendorst GR (1991) Connective tissue growth factor: a cysteine-rich mitogen secreted by human vascular endothelial cells is related to the SRC-induced immediate early gene product CEF-10 Journal of Cell Biology 114 1285-1294

Brigstock DR (1999) The connective tissue growth factor/cysteine-rich 61/nephroblastoma overexpressed (CCN) family Endocrine Reviews 20 189-206

Brigstock DR, Steffen CL, Kim GY, Vegunta RK, Diehl JR and Harding PA (1997) Purification and characterization of novel heparin-binding growth factors in uterine secretory fluids. Identification as heparinregulated $\mathrm{M}, 10,000$ forms of connective tissue growth factor Journal of Biological Chemistry 27220 275-20 282

Chambers RC, Leoni P, Blanc-Brude OP, Wembridge DE and Laurent GJ (2000) Thrombin is a potent inducer of connective tissue growth factor production via proteolytic activation of protease-activated receptor-1 Journal of Biological Chemistry 27535 584-35 591

Chen CC, Chen N and Lau LF (2001) The angiogenic factors Cyr61 and connective tissue growth factor induce adhesive signaling in primary human skin fibroblasts Journal of Biological Chemistry 276 $10443-10452$

Chen N, Chen CC and Lau LF (2000) Adhesion of human skin fibroblasts to Cyr61 is mediated through integrin $\alpha 6 \quad \beta 1$ and cell surface heparan sulfate proteoglycans Journal of Biological Chemistry 275 24 953-24 961

Chen Y, Segarini P, Raoufi F, Bradham D and Leask A (2001) Connective tissue growth factor is secreted through the Golgi and is degraded in the endosome Experimental Cell Research 271 109-117

Clarkson MR, Gupta S, Murphy M, Martin F, Godson C and Brady HR (1999) Connective tissue growth factor: a potential stimulus for glomerulosclerosis and tubulointerstitial fibrosis in progressive renal disease Current Opinions in Nephrology and Hypertension 8 543-548

Delmolino LM, Stearns NA and Castellot JJ, Jr (2001) COP-1, a member of the CCN family, is a heparin-induced growth arrest specific gene in vascular smooth muscle cells Journal of Cellular Physiology $\mathbf{1 8 8}$ $45-55$

Denton CP and Abraham DJ (2001) Transforming growth factor-beta and connective tissue growth factor: key cytokines in scleroderma pathogenesis Current Opinion in Rheumatology 13 505-511

Elovitz MA, Saunders T, Ascher-Landsberg J and Phillippe M (2000) Effects of thrombin on myometrial contractions in vitro and in vivo. American Journal of Obstetrics and Gynecology 183 799-804

Esko JD, Stewart TE and Taylor WH (1985) Animal cell mutants defective in glycosaminoglycan biosynthesis Proceedings National Academy of Sciences USA 82 3197-3201

Fan WH and Karnovsky MJ (2000) Activation of protein kinase C inhibits the expression of connective tissue growth factor Biochemical and Biophysical Research Communications 275 312-321

Frazier K, Williams S, Kothapalli D, Klapper H and Grotendorst GR (1996) Stimulation of fibroblast cell growth, matrix production, and granulation tissue formation by connective tissue growth factor Journal of Investigative Dermatology 107 404-411

Frazier KS and Grotendorst GR (1997) Expression of connective tissue growth factor mRNA in the fibrous stroma of mammary tumors International Journal of Biochemisty and Cell Biology 29 153-161

Geisert RD, Chamberlain CS, Vonnahme KA, Malayer JR and Spicer LJ (2001) Possible role of kallikrein in proteolysis of insulin-like growth factor binding proteins during the oestrous cycle and early pregnancy in pigs Reproduction $121719-728$

Goldschmeding R, Aten J, Ito Y, Blom I, Rabelink T and Weening JJ (2000) Connective tissue growth factor: just another factor in renal fibrosis? Nephrology, Dialysis, Transplantation 15 296-299

Grotendorst GR (1997) Connective tissue growth factor: a mediator of TGF-beta action on fibroblasts Cytokine and Growth Factor Reviews 8 $171-179$

Gupta S, Clarkson MR, Duggan J and Brady HR (2000) Connective tissue growth factor: potential role in glomerulosclerosis and tubulointerstitial fibrosis Kidney International 58 1389-1399
Harlow CR and Hillier SG (2002) Connective tissue growth factor in the ovarian paracrine system Molecular and Cellular Endocrinology 187 23-27

Harlow CR, Davidson L, Burns KH, Yan C, Matzuk MM and Hillier SG (2002) FSH and TGF-beta superfamily members regulate granulosa cell connective tissue growth factor gene expression in vitro and in vivo. Endocrinology 143 3316-3325

Howell DC, Goldsack NR, Marshall RP, McAnulty RJ, Starke R, Purdy G, Laurent GJ and Chambers RC (2001) Direct thrombin inhibition reduces lung collagen, accumulation, and connective tissue growth factor mRNA levels in bleomycin-induced pulmonary fibrosis American Journal of Pathology 159 1383-1395

Igarashi A, Okochi H, Bradham DM and Grotendorst GR (1993) Regulation of connective tissue growth factor gene expression in human skin fibroblasts and during wound repair Molecular Biology of the Cell $\mathbf{4}$ 637-645

Inoki I, Shiomi T, Hashimoto G, Enomoto H, Nakamura H, Makino K, Ikeda E, Takata S, Kobayashi K and Okada Y (2002) Connective tissue growth factor binds vascular endothelial growth factor (VEGF) and inhibits VEGF-induced angiogenesis FASEB Journal 16 219-221

Jedsadayanmata A, Chen CC, Kireeva ML, Lau LF and Lam SC (1999) Activation-dependent adhesion of human platelets to Cyr61 and Fisp12/mouse connective tissue growth factor is mediated through integrin alpha(Ilb)beta(3) Journal of Biological Chemistry 27424321 24327

Kim HS, Nagalla SR, Oh Y, Wilson E, Roberts CT, Jr and Rosenfeld RG (1997) Identification of a family of low-affinity insulin-like growth factor binding proteins (IGFBPs): characterization of connective tissue growth factor as a member of the IGFBP superfamily Proceedings National Academy of Sciences USA 9412 981-12 986

Kireeva ML, Latinkic BV, Kolesnikova TV, Chen CC, Yang GP, Abler AS and Lau LF (1997) Cyr61 and Fisp12 are both ECM-associated signaling molecules: activities, metabolism, and localization during development Experimental Cell Research 233 63-77

Kumar S, Hand AT, Connor JR et al. (1999) Identification and cloning of a connective tissue growth factor-like cDNA from human osteoblasts encoding a novel regulator of osteoblast functions Journal of Biological Chemistry 27417 123-17 131

Lau LF and Lam SC (1999) The CCN family of angiogenic regulators: the integrin connection Experimental Cell Research 248 44-57

Liu J, Kosma VM, Vanttinen T, Hyden-Granskog C and Voutilainen R (2002) Gonadotrophins inhibit the expression of insulin-like growth factor binding protein-related protein-2 mRNA in cultured human granulosaluteal cells Molecular Human Reproduction 8 136-141

Mori T, Kawara S, Shinozaki M, Hayashi N, Kakinuma T, Igarashi A, Takigawa M, Nakanishi T and Takehara K (1999) Role and interaction of connective tissue growth factor with transforming growth factor-beta in persistent fibrosis: a mouse fibrosis model Journal of Cellular Physiology 181 153-159

Moussad EE and Brigstock DR (2000) Connective tissue growth factor: what's in a name? Molecular Genetics and Metabolism 71 276-292

Moussad EE, Rageh MA, Wilson AK, Geisert RD and Brigstock DR (2002) Temporal and spatial expression of connective tissue growth factor (CCN2; CTGF) and transforming growth factor beta type 1 (TGF-beta1) at the utero-placental interface during early pregnancy in the pig Molecular Pathology 55 186-192

Nakanishi T, Kimura $Y$, Tamura T, Ichikawa $H$, Yamaai $Y$, Sugimoto $T$ and Takigawa M (1997) Cloning of a mRNA preferentially expressed in chondrocytes by differential display-PCR from a human chondrocytic cell line that is identical with connective tissue growth factor (CTGF) mRNA Biochemical and Biophysical Research Communications 234 206-210

Nakanishi T, Nishida T, Shimo T, Kobayashi K, Kubo T, Tamatani T, Tezuka K and Takigawa M (2000) Effects of CTGF/Hcs24, a product of a hypertrophic chondrocyte-specific gene, on the proliferation and differentiation of chondrocytes in culture Endocrinology 141 264-273

Nakanishi T, Yamaai T, Asano M, Nawachi K, Suzuki M, Sugimoto T and Takigawa M (2001) Overexpression of connective tissue growth factor/hypertrophic chondrocyte-specific gene product 24 decreases 
bone density in adult mice and induces dwarfism Biochemical and Biophysical Research Communications 281 678-681

Nishida T, Nakanishi T, Shimo T, Asano M, Hattori T, Tamatani T, Tezuka K and Takigawa M (1998) Demonstration of receptors specific for connective tissue growth factor on a human chondrocytic cell line (HCS2/8) Biochemical and Biophysical Research Communications 247 905-909

Nishida T, Nakanishi T, Asano M, Shimo T and Takigawa M (2000) Effects of CTGF/Hcs24, a hypertrophic chondrocyte-specific gene product, on the proliferation and differentiation of osteoblastic cells in vitro. Journal of Cellular Physiology 184 197-206

Pawar S, Kartha S and Toback FG (1995) Differential gene expression in migrating renal epithelial cells after wounding Journal of Cellular Physiology 165 556-565

Pendurthi UR, Allen KE, Ezban M and Rao LV (2000) Factor VIla and thrombin induce the expression of Cyr61 and connective tissue growth factor, extracellular matrix signaling proteins that could act as possible downstream mediators in factor VIla $\mathrm{x}$ tissue factor-induced signal transduction Journal of Biological Chemistry 27514 632-14 641

Perbal B (2001) NOV (nephroblastoma overexpressed) and the CCN family of genes: structural and functional issues Molecular Pathology $\mathbf{5 4}$ $57-79$

Rageh MAE, Moussad EE, Wilson AK and Brigstock DR (2001) Steroidal regulation of connective tissue growth factor (CCN2;CTGF) synthesis in the mouse uterus Molecular Pathology 54 338-346

Ross AK, Nelson KG, Sakai Y, Fukamachi H, Burroughs CD and McLachlan JA (1993) Isolation and culture of mouse uterine epithelial and stromal cells. In Female Reproductive Toxicology pp 371-385 Eds JJ Heindel and RE Chapin. Academic Press, San Diego, CA

Sampath D, Zhu Y, Winneker RC and Zhang Z (2001a) Aberrant expression of Cyr61, a member of the CCN (CTGF/Cyr61/Cef10/NOVH) family, and dysregulation by 17 beta-estradiol and basic fibroblast growth factor in human uterine leiomyomas Journal of Clinical Endocrinology and Metabolism 86 1707-1715

Sampath D, Winneker RC and Zhang Z (2001b) Cyr61, a member of the CCN family, is required for MCF-7 cell proliferation: regulation by 17 beta-estradiol and overexpression in human breast cancer Endocrinology 142 2540-2548

Sampath D, Winneker RC and Zhang Z (2002) The angiogenic factor Cyr61 is induced by the progestin R5020 and is necessary for mammary adenocarcinoma cell growth Endocrine 18 147-159

Schober JM, Chen N, Grzeszkiewicz TM, Jovanovic I, Emeson EE, Ugarova TP, Ye RD, Lau LF and Lam SC (2002) Identification of integrin alpha(M)beta(2) as an adhesion receptor on peripheral blood monocytes for Cyr61 (CCN1) and connective tissue growth factor (CCN2): immediate-early gene products expressed in atherosclerotic lesions Blood 99 4457-4465

Schwab JM, Postler E, Nguyen TD, Mittelbronn M, Meyermann R and Schluesener HJ (2000) Connective tissue growth factor is expressed by a subset of reactive astrocytes in human cerebral infarction Neuropathology and Applied Neurobiology 26 434-440

Shimo T, Nakanishi T, Nishida T et al. (1999) Connective tissue growth factor induces the proliferation, migration, and tube formation of vascular endothelial cells in vitro, and angiogenesis in vivo. Journal of Biochemistry (Tokyo) 126 137-145

Slee RB, Hillier SG, Largue P, Harlow CR, Miele G and Clinton M (2001) Differentiation-dependent expression of connective tissue growth factor and lysyl oxidase messenger ribonucleic acids in rat granulosa cells Endocrinology 142 1082-1089

Steffen CL, Ball-Mirth DK, Harding PA, Bhattacharyya N, Pillai S and Brigstock DR (1998) Characterization of cell-associated and soluble forms of connective tissue growth factor (CTGF) produced by fibroblast cells in vitro. Growth Factors 15 199-213

Surveyor GA, Wilson AK and Brigstock DR (1998) Localization of connective tissue growth factor during the period of embryo implantation in the mouse Biology of Reproduction 59 1207-1213
Tsai MS, Hornby AE, Lakins J and Lupu R (2000) Expression and function of CYR61, an angiogenic factor, in breast cancer cell lines and tumor biopsies Cancer Research 60 5603-5607

Tsai MS, Bogart DF, Li P, Mehmi I and Lupu R (2002) Expression and regulation of Cyr61 in human breast cancer cell lines Oncogene $\mathbf{2 1}$ 964-973

Ujike K, Shinji T, Hirasaki S, Shiraha H, Nakamura M, Tsuji T and Koide $\mathbf{N}$ (2000) Kinetics of expression of connective tissue growth factor gene during liver regeneration after partial hepatectomy and D-galactosamineinduced liver injury in rats Biochemical and Biophysical Research Communications 277 448-454

Uzumcu M, Homsi MF, Ball DK, Coskun S, Jaroudi K, Hollanders JM and Brigstock DR (2000) Localization of connective tissue growth factor in human uterine tissues Molecular Human Reproduction 6 1093-1098

Valdes G, Corthorn J and Figueroa CD (1998) The kallikrein-kinin system along the different stages of gestation: experimental and clinical findings Biological Research 31 235-241

Valdes G, Chacon C, Corthorn J, Figueroa CD and Germain AM (2001) Tissue kallikrein in human placenta in early and late gestation Endocrine 14 197-204

Vonnahme KA, Malayer JR, Spivey HO, Ford SP, Clutter A and Geisert RD (1999) Detection of kallikrein gene expression and enzymatic activity in porcine endometrium during the estrous cycle and early pregnancy Biology of Reproduction 61 1235-1241

Wahab NA, Yevdokimova N, Weston BS, Roberts T, Li XJ, Brinkman H and Mason RM (2001) Role of connective tissue growth factor in the pathogenesis of diabetic nephropathy Biochemical Journal 359 77-87

Wandji SA, Gadsby JE, Barber JA and Hammond JM (2000) Messenger ribonucleic acids for MAC25 and connective tissue growth factor (CTGF) are inversely regulated during folliculogenesis and early luteogenesis Endocrinology 141 2648-2657

Williams EJ, Gaca MD, Brigstock DR, Arthur MJ and Benyon RC (2000) Increased expression of connective tissue growth factor in fibrotic human liver and in activated hepatic stellate cells Journal of Hepatology 32754 761

Wunderlich K, Senn BC, Reiser P, Pech M, Flammer J and Meyer P (2000) Connective tissue growth factor in retrocorneal membranes and corneal scars Ophthalmologica 214 341-346

Xie D, Miller CW, O'Kelly J, Nakachi K, Sakashita A, Said JW, Gornbein J and Koeffler HP (2001a) Breast cancer. Cyr61 is overexpressed, estrogen-inducible, and associated with more advanced disease Journal of Biological Chemistry 27614 187-14 194

Xie D, Nakachi K, Wang H, Elashoff $\mathbf{R}$ and Koeffler HP (2001b) Elevated levels of connective tissue growth factor, WISP-1, and CYR61 in primary breast cancers associated with more advanced features Cancer Research 61 8917-8923

Yang DH, Kim HS, Wilson EM, Rosenfeld RG and Oh Y (1998) Identification of glycosylated 38-kDa connective tissue growth factor (IGFBP-related protein 2) and proteolytic fragments in human biological fluids, and up-regulation of IGFBP-rP2 expression by TGF-beta in Hs578T human breast cancer cells Journal of Clinical Endocrinology and Metabolism $832593-2596$

Yang GP and Lau LF (1991) Cyr61, product of a growth factor-inducible immediate early gene, is associated with the extracellular matrix and the cell surface Cell Growth and Differentiation 2 351-357

Zhang R, Averboukh L, Zhu W, Zhang H, Jo H, Dempsey PJ, Coffey RJ, Pardee AB and Liang $\mathbf{P}$ (1998) Identification of rCop-1, a new member of the $\mathrm{CCN}$ protein family, as a negative regulator for cell transformation Molecular and Cellular Biology 18 6131-6141

Received 20 August 2002.

First decision 18 October 2002.

Revised manuscript received 7 November 2002.

Accepted 14 November 2002 